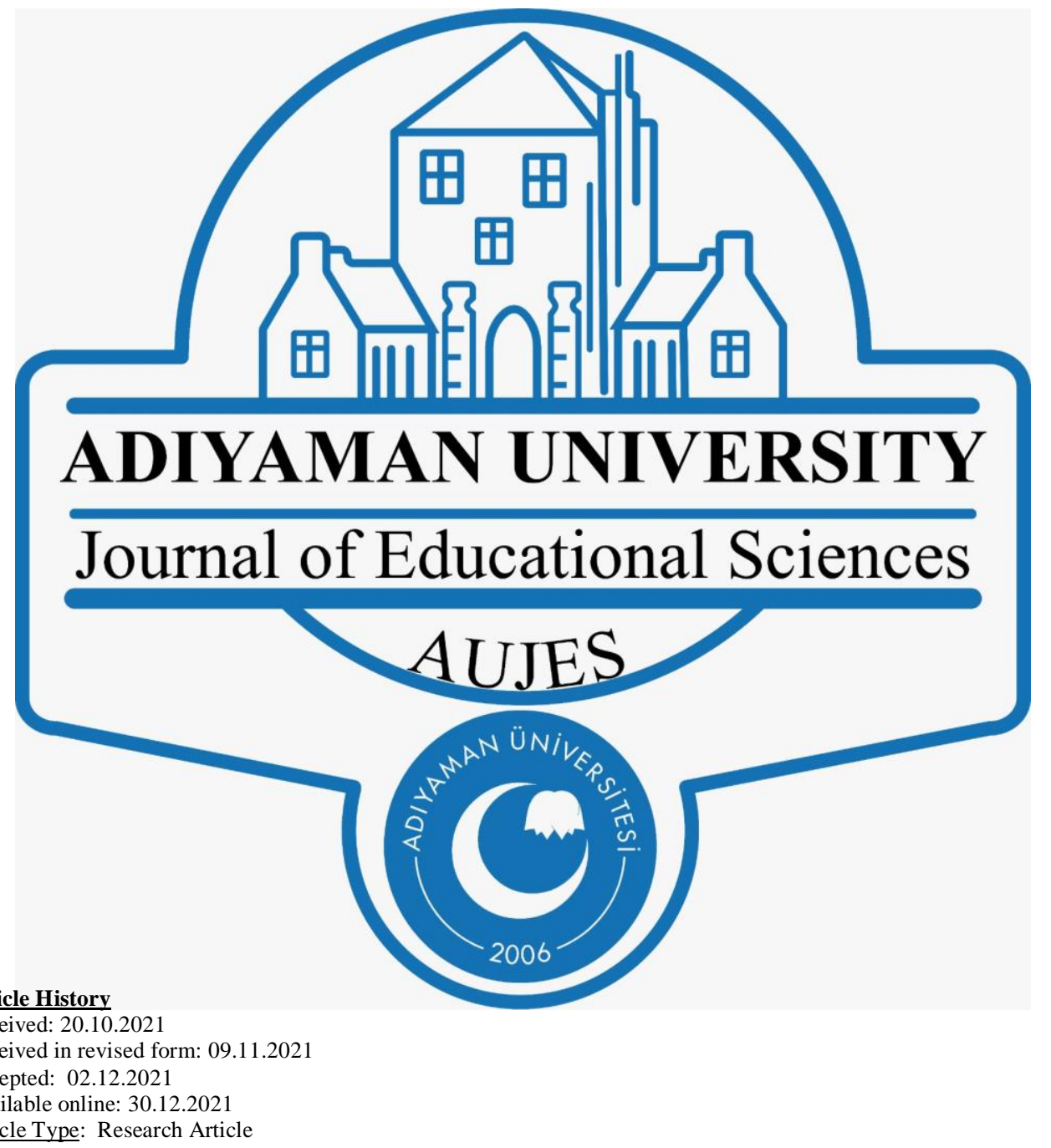

Article Type: Research Article

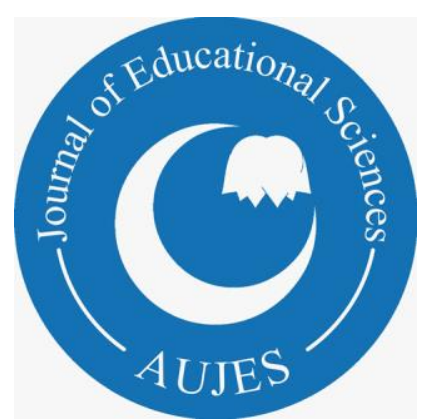

ADIYAMAN UNIVERSITY Journal of Educational Sciences (AUJES) https://dergipark.org.tr/tr/pub/adyuebd

Overcoming the Obstacles of Peace Education through Wellbeing Practices

\section{Gulistan Gursel-Bilgin ${ }^{1}$ (Corresponding Author), Elif Bengu ${ }^{2}$ \\ ${ }^{1}$ Bogazici University, Istanbul, Turkey (D) \\ ${ }^{2}$ Abdullah Gul University, Kayseri, Turkey iD}

To cite this article:

Gursel-Bilgin, G. \& Bengu, E. (2021) Overcoming the Obstacles of Peace Education through Wellbeing Practices. Adiyaman Univesity Journal of Educational Sciences, 11(2), 80-92. 


\title{
Overcoming the Obstacles of Peace Education through Wellbeing Practices
}

\author{
Gulistan Gursel-Bilgin ${ }^{1 *}$, Elif Bengu ${ }^{2}$ \\ ${ }^{1}$ Bogazici University, Istanbul, Turkey gulistan.bilgin@ boun.edu.tr \\ ${ }^{2}$ Abdullah Gul University, Kayseri, Turkey elif.bengu@agu.edu.tr
}

\begin{abstract}
A growing body of literature reports structural, cultural, social, and political barriers making it challenging and stressful to integrate peace education in teacher education and in-service teacher education programs. To support peace educators in achieving what they stand for, this study proposes integrating wellbeing practices and approaches into the curricula. Drawing from the fields of peace education, educational leadership and policy studies and higher education, this study examines wellbeing as a potentially promising scholarly field to support peace education scholarship. For happiness and life satisfaction, wellbeing links a person's physical, mental, emotional and social health factors not just to internal factors such as optimism, resilience and self-esteem but also external factors such as income, satisfaction at work and social networks. In order to explore the ways wellbeing can contribute to peace education, we first expand on peace education as a controversial and challenging practice especially for practitioners in the field. Next, we discuss wellbeing practices as they relate to educational settings. Finally, we discuss that peace educators can be supported by wellbeing practices to overcome the degrading and demotivating effects of their practices.
\end{abstract}

Key words: Peace education, higher education, wellbeing, teacher training, pedagogy.

\section{Introduction}

Formal schooling is portrayed with a unique potential in transforming present violent realities and inequalities into peaceful and just social orders (Bajaj, 2008; Bickmore, 2011; Flinders, 2005, 2006; Gursel-Bilgin, 2016; 2020a;2020b; 2021; Hutchinson \& Herborn, 2012; Noddings, 2012) On the other hand, there is a growing body of literature reporting structural, cultural, social, and political barriers making it challenging, if not impossible, to integrate peace education in teacher education and in-service teacher education programs (Bekerman \& Zembylas, 2014; Burnley, 2003; Cook, 2014; Harris \& Morrison, 2003; Horsley, et al., 2005; McLean, et al., 2008; Wang, 2018) Within such a challenging and discouraging context, teachers interested in practicing peace education are under particular stress and pressure (Burnley, 2003; Horsley, et al., 2005).

Drawing from the fields of peace education and educational leadership and policy studies and higher education, this study examines wellbeing as a potentially promising scholarly field to support peace education scholarship. It is guided by the question: What offerings do wellbeing present in order to contribute to peace education? Below, we expand on peace education as a controversial and challenging practice especially for practitioners in the field. We also discuss that peace educators need to be supported by wellbeing practices to overcome the degrading and demotivPating effects of their peace education practices.

\footnotetext{
* Corresponding Author: Gulistan Gursel-Bilgin, gulistan.bilgin@ boun.edu.tr
} 


\section{Peace education as a challenging practice}

Education and peace are perceived to be inherently interconnected (Danesh, 2007; Trifonas \& Wright, 2011), and peace education is presumed to be integrally incorporated in teacher education programs (Brantmeier, 2010; Bekerman \& Zembylas, 2014). However, a large volume of literature underlines the opposite in reality for both teacher education programs and practicing teachers (Bekerman \& Zembylas, 2014). Pre-service teachers are hesitant towards peace education as they find peace education stressful and challenging compared to citizenship, environmentalism, and multiculturalism despite their close link with peace education (Burnley, 2003; Cook, 2014; Wang, 2018). Others have found that peace education was perceived to be linked with ethnic movements (Burnley, 2003). Pre-service teachers had limited understanding of peace education and struggled to integrate dimensions of peace education into their practice teaching (Cook, 2014).

Likewise, literature on peace education integration in in-service teacher training reports challenges (Bekerman \& Zembylas, 2014; Clarke-Habibi, 2018; Lopes Cardozo \& Hoeks, 2015; Zembylas et al., 2016; Zembylas \& Bekermanc, 2019; Zembylas \& Loukaidis, 2020). For example, peace educators are regarded as communist sympathizers (Burnley, 2003), and unpatriotic and disloyal to their homeland (Horsley, et al., 2005). Such negative perceptions of peace educators and teachers' fear of disapproval by their employers and society discourage teachers from integrating peace education into their teaching (Horsley, et al., 2005). In line with this, McLean, Cook \& Crowe (2008) discuss that practicing teachers also had limited understandings of what peace and peace education entails. As a result, their efforts of integrating peace education into their curriculum and teaching often resulted in ineffective lesson planning and practice.

Several psychological, cultural, political, and educational obstacles influence peace educators' perceptions and practices of peace education (Harris \& Morrison, 2003). One critical example is the case of the Peace Teacher, who lost her job and home in the state in the aftermath of her only statement "I honk for peace" when asked by one of her elementary school students about her opinion about the war in Iraq. As result of the complaint of one of the parents, apart from losing her job and home, she had to go through several court cases, including federal courts, that ruled she had no right of free speech, only a commodity to sell to her employer, the public school. This study is crucial because it scrutinizes the missions and functions of public schooling within the society and shows how it can operate in support of power inequalities. Furthermore, the study illustrates the dynamics in charge in which peace education exists as a controversial issue that is discouraging for teachers to integrate into their curricula and teaching. This is in line with other studies that emphasize that peace education implies criticism of the present social, cultural, religious, and political norms that result in inequalities in the society (Harris \& Morrison, 2003; Westheimer, 2007).

In Turkey, teacher education programs most frequently do not include courses on multicultural education, environmental education, and global education (Gurdogan-Bayir \& Bozkurt, 2018, Erbas, 2019) that prepare future teachers to effectively integrate peace education into their teaching practice (Christopher \& Taylor, 2011; Cook, 2014). Factors such as the lack of educated faculty members to teach these courses as well as limited financial resources are among possible reasons for this (Akar, 2010; Çelik \& Gür, 2014; Çetinsaya, 2014; Gök, 2016; Kurt \& Gümüş, 2014; Simsek, 2007). As a result, teachers in Turkey most frequently are inadequately prepared in order to integrate peace education into their curriculum and practice.

The challenges peace educators are likely to face in their practices of integrating peace education into their curricula are well-reported in the literature (e.g., Gursel-Bilgin, 2016, 
2017, 2020b, 2021; Gursel-Bilgin \& Flinders, 2020; 2021; Darder, 2012; Harris \& Morrison, 2003; Navarro-Castro \& Nario-Galace, 2008; Noddings, 2012; Zamir, 2009; Zartman, 2007). For example, Zartman (2007) identifies the elusive nature of the definitions of peace, insufficient pedagogical methods, controversial class materials and topics, and lack of comprehensive evaluation of programs focused on the peace education practices and their outcomes. Closely linked with these challenges are pedagogical obstacles for peace education practitioners: emotional and cognitive mistrust towards peace education, expressions of stereotypes often promoted by media, the politicization of peace education often leading to propaganda, and the existence of culture of war interwoven into social norms and values and reflected in school culture and curricula (Zamir, 2009).

\section{Wellbeing of Teachers}

A growing body of literature emphasizes the significance of teacher wellbeing in educating future generations effectively (Acton \& Glasgow, 2015; Hwang et al., 2017; Vesely et al., 2014). This emphasis has only become stronger with the circumstances resulting from the Covid-19 pandemic (Dabrowski, 2021; Gadermann et al., 2021). Reviewing the literature, the wellbeing of educators from the perspective of burnout, occupational stress (Vesely et al., 2014), anxiety and depression (Hwang et al., 2017) are also emerging as significant. Defining wellbeing may be crucial in the context of this study as there are various understandings and explanations of wellbeing in the literature (Acton \& Glasgow, 2015; La Placa et al., 2013).

In their book Rath \& Harter (2010) conducted a comprehensive study with Gallup, an American analytics and advisory company known for its public opinion polls conducted worldwide, and collected participants' data in more than 150 countries. As a result of their study, they revealed five universal, interconnected elements and defined wellbeing as the interaction of these five elements:

1. Career wellbeing is about how you occupy your time or simply liking what you do every day.

2. Social wellbeing is about having strong relationships and love in your life.

3. Financial wellbeing is about effectively managing your economic life

4. Physical wellbeing is about having good health and enough energy to get things done on a daily basis

5. Community wellbeing is about the sense of engagement you have with the area where you live

They found out that only $7 \%$ are successful in all five elements and $66 \%$ of people are doing well in at least one of these areas. When we are talking about wellbeing and factors that may affect someone's health or happiness, we should look at that person holistically and consider both external conditions, such as income, satisfaction at work and social networks and internal conditions, such as optimism, resilience and self-esteem (Rath \& Harter, 2010; Şinik, 2018). To strengthen our wellbeing, we should strengthen all of these five elements and to be able to do that one should take care and balance their mind, body and spirit so that they feel capable, resilient and in harmony with those around them (Rath \& Harter, 2010; Şinik, 2018). An alternative medicine advocate Dr. Chopra (1991) mentioned five items as a holistic health indicator. The first indicator of overall health is to have an energetic and healthy body; the second is to have a calm, clear and cheerful mind; the third is a heart full of love and kindness; and the fourth indicator is an awareness of one's existence and purpose in life. His life-long research and related literature (Chopra \& Tanzi, 2018) found stress as one of the biggest factors affecting the overall health. Other factors enhancing and strengthening our wellbeing are having enough sleep, clean eating, and having a healthy digestive system. Various methods integrate wellbeing approaches in terms of stress management and 
to create a balance between mental, spiritual and physical health. The ones that are commonly used with teachers are emotional intelligence (EI), mindfulness-based practices, contemplative pedagogy, and positive education. Before briefly discussing these methods, in this particular study wellbeing of teachers refers to teachers' awareness of their personal and professional purpose and goals, ability to work harmoniously with themselves and with others, and having sense of personal and professional fulfilment, satisfaction, and happiness (Soini et al., 2010) within their contextual factors.

\section{Methods that are Commonly Used with Teachers to Enhance their Wellbeing}

1. Emotional intelligence (EI): Development of emotional intelligence as a competence facilitates the identification and regulations of emotions that increase stress (Austin et al., 2005; Hansen et al., 2007; Vesely et al., 2014). Research has shown that emotional competence enhances the management of occupational stress and contributes to teacher efficiency in the workplace. Hansen et al. (2007) conducted a study on EI that is used to regulate emotions and enhance stress management. They designed a stress management program that was administered for pre-service teachers for over a five-week period. They found that EI can be used to regulate emotions, enhance stress management, also amplify teacher wellbeing and classroom performance. In 2014, Vesely et al. did a similar study with pre-service teachers; their findings are in line with Hansen et al. (2007). At the end of their 5-week EI training program Vesely, et al. (2014) observed that the teachers' stress and anxiety levels are decreased and their capacity to cope with occupational stress are increased.

2. Mindful based practices: Kabat-Zinn (2011) defined mindfulness as paying attention and being in a present moment in a non-judgmental stage. He developed the Mindfulness-Based Stress Reduction (MBSR) program that includes methods such as mindful eating, walking, exercising, meditation and silence retreat and found that the program successfully reduces the stress of people with chronic health problems (Kabat-Zinn, 2011). Hwang et al. (2017) conducted a systematic review that was done on implementation of mindfulness-based practices for in-service teachers. They found that mindfulness-based practices adopted from Kabat Zinn reported improvements in teachers' psychological and behavioral health, an increase in commitment to their profession, and positive effects on reducing teachers' stress and burn-out.

3. Contemplative pedagogy: Contemplative teaching includes methods such as guided meditation, keeping journals, practicing silence, music, art, poetry, dialogue, and questions to "quiet and shift the habitual chatter of the mind to cultivate a capacity for deepened awareness, concentration, and insight" (Chick, 2010, p. 2). According to Bush (2006) contemplative pedagogy is becoming a scholarly field; however, its roots go back to 1997 where Williams James addressed it as "the power of mindful learning" (p.3).

4. Positive education: Seligman et al. (2009) defined positive education as "education for both traditional skills and for happiness" (Seligman et al. 2009, p. 293). They conduct their study in Australia to define positive education as new prosperity for both wealth and well-being. They tested two different programs for schools, the Penn Resiliency Program (PRP) and the Strath Haven Positive Psychology Curriculum. They found that both of these programs "produce positive and reliable improvements in students' well-being” (Seligman et al. 2009, p. 303).

Although these four, emotional intelligence, mindfulness-based practices, contemplative pedagogy and positive education are taken as different methods, they all 
"involve teaching methods designed to cultivate deepened awareness, concentration, and insight" (Chick, 2010, p. 1) about one-self to enhance personal and professional wellbeing.

Chick (2010) emphasized the importance of meditation and how it can be used to increase creativity in education. In the guide to be able to act on situations adequately, she recommends educators to "engage in regular meditation practice" (Chick 2010, p. 4). To increase participating teachers' wellbeing, the University of Virginia created a program called Cultivating Awareness and Resilience in Education (CARE). Their goal was to increase the wellbeing of participants by "providing them with specific skills and practices to better cope with classroom demands" (Breen, 2016, p. 1). They found out that educators that use methods and strategies regularly to reduce their stress "increase their abilities to cope with the demands of the career and are positioned to do a better job educating students" (pg.2). Shapiro et al.'s (2008) empirical study emphasized that meditation can be used as an effective tool to support students' mental health under stress. Following what they have highlighted in their study, it can be said that meditation may be used to well-prepare educators for the social and emotional demands of the classroom and build "stress resilience" (p.3) of educators (Shapiro et al., 2008). Similarly, Turkey's researchers at a mid-size public university observed that student and instructor motivation levels drastically decreased (Cihan-Aydoğdu $\&$ Tok, 2021). The co-author of this article and her colleague designed a workshop for 8 weeks for undergraduate students to explore the influence of contemplative pedagogy and positive education on students' wellbeing. The workshop aimed to raise students' awareness of wellbeing and introduce them with practice to reduce stress levels and increase motivation for learning. In conjunction with meditation, breathing and qigong exercises, issues such as healthy eating habits, sleeping patterns and aromatherapy were discussed together by inviting experts from the fields. The small-scale case study findings supported that a practice of these methods increases students' motivation and decreases their stress levels within the framework of the relevant literature (Cihan-Aydoğdu \& Bengü, 2021).

\section{Discussion}

Teaching has been ranked as one of the most stressful jobs (Johnson et al. 2005). Given the challenging nature and context of teaching due to organizational, social and economic factors, one does not need to be an expert to see how challenging and stressful teachers' personal and professional life could be (Kokkinos 2007; Spilt, 2011). In peace education classrooms, these challenges only increase compared to other classes as it was discussed above.

To nourish and protect themselves and their learners, peace education practitioners need to be equipped with special techniques and practices. We believe that wellbeing approaches that are discussed in this study provide support for peace teachers in coping with the stressful environments they are in. This section discusses how wellbeing approaches can benefit teachers' personal and professional environments under two different subtitles.

\section{The Individual Benefits of Practicing Wellbeing for Peace Educators}

Teachers are more open to novelties when they are in a positive state (Fredrickson, 2012). In the case of peace educators, establishing and maintaining a positive state can be even more challenging as discussed in the related section above. In fact, peace educators, most frequently, if not always, find themselves swimming against the current due to the social, cultural, economic, religious, and political challenges they face while planning and teaching classes integrating various aspects of peace education (Darder, 2012; Gursel-Bilgin, 2016, 2017, 2020b, 2021; Gursel-Bilgin \& Flinders, 2020; 2021; Harris \& Morrison, 2003; Navarro-Castro \& Nario-Galace, 2008; Noddings, 2012; Zamir, 2009; Zartman, 2007). Given that peace starts from within and peaceful teachers will be more successful peace 
practitioners, caring for the wellbeing of peace educators is particularly vital. Considering that teachers are the most important factor in determining the success of any curriculum and program, the wellbeing of peace educators must be supported through related courses that can be integrated in teacher education programs as well as in-service training programs.

Teachers' wellbeing has a profound influence on learner wellbeing. Due to this direct influence, learner wellbeing and teacher wellbeing are considered the two sides of a coin (Roffrey, 2012). Teachers' satisfaction with their life and work is reflected in their interaction with others (Mifsud, 2011). In other words, teachers' wellbeing is highly contagious (Becker, 2014) due to its direct link to both academic and personal achievements and lives of learners (Briner \& Dewberry, 2007). Their students tend to decode the verbal and nonverbal signs in their communication and catch their teachers' moods, and eventually copy those in their own lives consciously or unconsciously (Mercer \& Gregersen, 2020). What is more interesting is the mutual nature of this influence. Positive rapport between learners and teachers directly influences teachers because research suggests that happy and motivated students increase teachers job satisfaction (Mercer \& Gregersen, 2020).

Research on teacher wellbeing is vital especially to better understand their concerns and challenges, and so prevent teacher burnout; to help teachers develop and/or increase positive attitudes towards school reforms and contribute to social transformation; improve learners' socioemotional and academic lives (Lochman 2003; Moolenaar 2010; Spilt et al., 2011; van Veen et al. 2005). Most empirical research has focused on social and organizational factors that influence teacher wellbeing (Spilt, 2011). The factors studied broadly include lack of supportive community and supervision, administrational and instructional workload, and issues related to classroom management (Kokkinos 2007). Although the teacher-student rapport and its effects on the lives of learners have been extensively studied (Frisby et al., 2017; Frisby et al., 2020; Frisby \& Martin, 2010; Sidelinger et al., 2016) the influence of learners on teacher wellbeing is understudied in the related literature (Friedman, 2000; Spilt, 2011). Considering the interpersonal nature of the interaction between teachers and learners, the complexities and challenges teachers experience as a result of this interaction and relationship with learners are yet to be explored (Spilt, 2011). Therefore, future research would do well to explore the reflections of these factors on the personal wellbeing of teachers, and ways to improve teachers' positive state effectively.

\section{The Professional Benefits of Practicing Wellbeing for Peace Educators}

The limits of teachers' influence on learners are non-measurable. However, it is important to underline the multidimensionality of their influence. Although wellbeing practices are not widespread worldwide yet and there are few studies exploring their effects on learners (Soutter et al., 2012). The limited empirical findings underline the various benefits on the lives of the learners. Curriculum and instruction integrating wellbeing practices and approaches have been found to be beneficial for both learners and teachers. For example, Schwind et al. (2017) offered (five-minute) instructor-guided mindfulness practices over eight weeks at the beginning and end of classes to graduate and undergraduate students from various disciplines in an urban university. The participants also practiced mindful breathing techniques for five to fifteen minutes individually at home. The results emphasized increased learner and teacher wellbeing with decreased anxiety and stress, and more respectful and peaceful class environment (Schwind et al., 2017). These findings are in line with others emphasizing beneficial effects of mindful practices in terms of increased wellbeing (Hassed \& Chambers, 2014; Smalley \& Winston, 2010;).

Wellbeing practices when integrated into school curricula and instruction result in several benefits for learners. For example, mindfulness practices integrated in undergraduate 
and graduate programs of higher education have been found to help learners effectively cope with anxiety and stress and increased personal wellbeing and academic achievement (Hassed and Chambers, 2014; Miller, 2012). The CARE program (Breen, 2016) discussed above is another example of the effectiveness of the way we teach. In the program, the teachers receiving the wellness training also positively influenced the qualities of their classes. They were able to demonstrate greater sensitivity towards the needs of their students and better support their students emotionally than those teachers who did not receive the training.

Considering the social, organizational, cultural, religious, and political pressures peace educators and learners experience while studying peace education, various forms of wellbeing practices might do wonders in helping them cope with those challenges. Besides using wellbeing as part of formal instruction of schooling experiences, they can also integrate wellbeing practices in the hidden or indirect curriculum. This can be achieved, for example, through the attitudes and behaviors of the teachers when they engage in interaction with others. The interactions of teachers with a positive state and high motivation will (in)directly influence the wellbeing of learners. Moreover, learners will obtain a chance to learn the related approaches and practices by observing their teachers. In peace education, the medium is at least as important as the message. The way we teach must be consistent with the content being taught, or in other words, "the medium must match the message (Navarro-Castro, 2010, p. 16). Wellbeing approaches and practices can help peace educators enrich their instructional materials and techniques to better fulfill what they stand for.

\section{Conclusion and Implications}

In this review study, we sought to understand how wellbeing approaches and practices such as emotional intelligence (EI), mindful based practices, contemplative pedagogy, and positive education contribute to peace education. According to research in the field, methods that are commonly used with teachers to enhance their wellbeing can be an antidote for their stress, may increase their life and work satisfaction, and can be used as an aid for positive engagement with themselves, their peers, students and environment. Although teaching is found to be a demanding and stressful profession in general, peace educators are specifically portrayed as swimming against the current due to the structural, cultural, social, and political challenges that exist within the school and higher education systems. These challenges make peace educators' job exceptionally tough. Therefore, focusing particularly on the needs of peace educators, we drew from higher education, peace education, and educational leadership and policy studies to examine the offerings of wellbeing practices towards supporting peace educators in their controversial and challenging practices. Although our primary focus in this study is peace education, we strongly believe that the implications expand to all subjects in schooling and school culture.

In this context this article may be considered a first in Turkey. There is value in increasing awareness regarding the critical conditions in which these teachers have to swim against the current and provide various methods to reduce emotional exhaustion and stress that they may experience at their workplace. In light of the discussion in the article, we can suggest that wellbeing interventions should be included in teacher training programs at higher education institutions and in-service programs. Embedding these practices into the whole curriculum may be seen risky at first. We suggest institutions, researchers and practitioners to pilot wellbeing approaches and practices with a small group of attendees and improving the process according to the outcomes. This may require creating funds for skilled trainers as wellbeing interventions should be implemented in a structured way. After gaining contextualized experience and insights, the existing curricula at both K-12 and higher 
education institutions can be reconsidered in order to integrate wellbeing practices across $\mathrm{K}$ 12 and higher education programs.

\section{References}

Acton, R. \& Glasgow, P. (2015). Teacher wellbeing in neoliberal contexts: A review of the literature. Australian Journal of Teacher Education, 40(8), 99-114. http://dx.doi.org/10.14221/ajte.2015v40n8.6.

Akar, H. (2010). Globalization and its challenges for developing countries: The case of Turkish higher education. Asia Pacific Education Review, 11(3), 447-457.

Austin, E. J., Saklofske, D. H., \& Egan, V. (2005). Personality, well-being and health correlates of trait emotional intelligence. Personality and Individual Differences, 38, 547-558. http://dx.doi.org/10.1016/j.paid.2004.05.009.

Bajaj, M. (2008). Critical peace education. In M. Bajaj, (Ed.) Encyclopedia of Peace Education. New York: Colombia Teacher's College.

Becker, B. D., Gallagher, K. C., \& Whitaker, R. C. (2017). Teachers' dispositional mindfulness and the quality of their relationships with children in Head Start classrooms. Journal of school psychology, 65, 40-53. https://doi.org/10.1016/j.jsp.2017.06.004

Bekerman, Z., \& Zembylas, M. (2014). Some reflections on the links between teacher education and peace education: Interrogating the ontology of normative epistemological premises. Teaching and Teacher Education, 41, 52-59. https://doi.org/10.1016/j.tate.2014.03.002

Bickmore, K. (2011). Education for "peace" in urban Canadian schools: Gender, culture, conflict, and opportunities to learn. In Critical issues in peace and education (pp. 88103). Routledge.

Brantmeier, E. J. (2011). Toward mainstreaming critical peace education in US teacher education. Critical pedagogy in the 21st century: A new generation of scholars, 349375.

Breen, A. (2016, May 2). Curry study: Reducing teachers' stress leads to higher-quality classrooms. UVA Today._https://news.virginia.edu/content/curry-study-reducingteachers-stress-leads-higher-quality-classrooms

Briner, R. \& Dewberry, C. (2007). Staff wellbeing is key to school success: A research study into the links between staff wellbeing and school performance. http://www.worklifesupport.com/sites/default/files/uploadeddocuments/5902Birkbeck WBPerfSummaryFinal.pdf

Burnley, J. (2003). From awareness to action: social studies and peace education. Education Links, 66, 21-24.

Bush, M. (2006). Foreword. Teachers College Record, 108, 1721-1722. https://www.tcrecord.org/Content.asp?ContentId=12675

Çelik, Z. \& Gür, B.S. (2014). Yükseköğretim sistemlerinin yönetimi ve üniversite özerkliği: küresel eğilimler ve Türkiye örneği. Yükseköğretim ve Bilim Dergisi, 4(1), 18-27.

Çetinsaya, G. (2014). Büyüme, kalite, uluslararasılaşma: Türkiye yükseköğretimi için bir yol haritas1. Yüksek Öğretim Kurulu. https://yolharitasi.yok.gov.tr/docs/YolHaritasi.pdf 
Chick, N. (2010). Mindfulness in the classroom. Vanderbilt University Center for Teaching. https://cft.vanderbilt.edu/guides-sub-pages/contemplative-pedagogy

Chopra, D. (1991). Perfect health. Transworld.

Chopra, D. \& Tanzi, R. E. (2018). The healing self: Supercharge your immune system and stay well for life. Rider.

Christopher, D., \& Taylor, M. (2011). Social justice and critical peace education: Common ideals guiding student teacher transformation. Journal of Peace Education, 8(3), 295313.

Cihan-Aydoğdu, C. \& Bengü, B. (2021). Holistic me: A pilot study of integrated approach for students' wellbeing. In Hakan Ergin \& Şahabettin Akşab (Eds.), Participation in higher education: Voices and Experiences: 5th International Higher Education Conference (pp. 59-71).

Cihan-Aydoğdu, C. \& Tok, Ö. (2021). Öğrenci gözünden çevrimiçi danışmanlık. 10. Üniversite Psikolojik Danışmanlığı Sempozyumu. Boğaziçi Üniversitesi.

Clarke-Habibi, S. (2018). Teachers' perspectives on educating for peace in Bosnia and Herzegovina. Journal of Peace Education, 15(2), 144-168, http://doi.org/10.1080/17400201.2018.1463209

Cook, S. A. (2014). Reflections of a peace educator: The power and challenges of peace education with pre-service teachers. Curriculum Inquiry, 44(4). https://doi.org/10.1111/curi.12058

Dabrowski, A. (2021). Teacher wellbeing during a pandemic: Surviving or thriving? Social Education Research, 2(1), 35-40. https://doi.org/10.37256/ser.212021588

Danesh, H. B. (2007). Education for peace: The pedagogy of civilization. In Z. Beckerman \& C. McGlynn (Eds.), Addressing ethnic conflict through peace education: International perspectives. Palgrave Macmillan.

Darder, A. (2012). In search of peace in a culture of war [Preface]. In P. Carr \& B. Profilio (Eds.), Educating for peace in a time of permanent war: Are schools' part of the solution or problem. Peter Lang.

Erbas, Y. H. (2019). A qualitative case study of multicultural education in Turkey: definitions of multiculturalism and multicultural education. International Journal of Progressive Education, 15(1), 23-43. https://doi.org/10.29329/ijpe.2019.184.2

Flinders, D. J. (2005). Adolescents talk about the war in Iraq. Phi Delta Kappa, 87(4). http://doi.org/10.1177/003172170508700413

Flinders, D. J. (2006). We can and should teach the war in Iraq. Education Digest, 71(5), 812.

Fredrickson, B. (2012). Love 2.0. How our supreme emotions affect everything we think, do, feel, and become. Hudson Street Press.

Friedman, I. A. (2000). Burnout in teachers: Shattered dreams of impeccable professional performance. Journal of Clinical Psychology, 56, 595-606.

Frisby, BN, \& Martin. MM. (2010). Instructor-student and student-student rapport in the classroom. Communication Education, 59(2), 146-164 
Frisby, BN., Hosek, A.M., \& Beck, AC. (2020). The role of classroom relationships as sources of academic resilience and hope. Communication Quarterly, 68(3), 289-305

Frisby, BN., Slone, AR., \& Bengu, E. (2017). Rapport, motivation, participation, and perceptions of learning in U.S. and Turkish student classrooms: a replication and cultural comparison. Communication Education, 66(2), 183-195. http://doi.org/10.1080/03634523.2016.1208259

Gadermann, A.M., Warren, M.T., Gagné, M., Thomson, K.C., Schonert-Reichl, K.A., Guhn, M., Molyneux, T.M., \& Oberle, E. (2021). The impact of the COVID-19 pandemic on teacher well-being in British Columbia. Human Early Learning Partnership. http://earlylearning.ubc.ca/

Gök, E. (2016). The Turkish higher education system from the kaleidoscope of Martin Trow. TED Eğitim ve Bilim, 41, 147-168.

Gursel-Bilgin, G. (2016). Dialogue for peace education: the case of an alternative school (Unpublished $\mathrm{PhD}$ Dissertation). Indiana University-Bloomington School of Education.

Gursel-Bilgin, G. (2017). Bells of war in the peace class: A critical look. In F. V. Tochon \& K. Harrison (Eds.) Policy for Peace: Language Education Unlimited (Language Education Policy). Language Education Policy Series. Deep University Press.

Gursel-Bilgin, G. (2020a). Freirean dialogue for peace education: A promising pedagogy for grassroots peace in the Middle East. Mediterranean Journal of Educational Research. 14(34), 84 - 105. http://10.29329/mjer.2020.322.4

Gursel-Bilgin, G. (2020b). Dialogue in peace education theory and practice. Educational Practice and Theory, 42(1), 27-46. doi:10.7459/ept/42.1.03

Gursel-Bilgin, G. (2021). Peace education as a controversial issue: A case study of "the peace case.” Citizenship, Teaching \& Learning, 16(1), 49-67(19). http://doi.org/10.1386/ctl_00037_1

Gursel-Bilgin, G., \& Flinders, D. (2020). Anatomy of a peace educator: Her work and workplace. Australian Journal of Teacher Education, 45(10). http:// 10.14221/ajte.2020v45n10.3

Gursel-Bilgin, G., \& Flinders, D. J. (2021). Teachers talk about war and peace. Curriculum and Teaching Dialogue, 23 (1\&2).

Gurdogan-Bayir, O., \& Bozkurt, M. (2018). War, peace, and peace education: Experiences and perspectives of pre-Service teachers. International Journal of Progressive Education, 14(1), 148-164.

Hansen, K, \& Gardner, L. (2007). Improving occupational stress through emotional intelligence development. Organizations \& People, 14(2), 70-75.

Harris, I., \& Morrison, M. L. (2003). Peace education [2nd ed.]. McFarland.

Hassed, C., \& Chambers, R. (2014). Mindful learning: Reduce stress and improve brain performance for effective learning exile. Pty. Ltd.

Horsley, M., Newell, S., \& Stubbs, B. (2005). The prior knowledge of global education of pre-service teacher education students. Citizenship, Social and Economic Education, 6(3), 137-155.

Hutchinson, F. P. \& Herborn, P. J. (2012). Landscapes for peace: a case study of active learning about urban environments and the future. Futures, 44, 24-35. 
Hwang, Y, Bartlett, B., Greben, M., \& Hand, K. (2017). A systematic review of mindfulness interventions for in-service teachers: A tool to enhance teacher wellbeing and performance. Teaching and Teacher Education, 64, 26-42. http://dx.doi.org/10.1016/j.tate.2017.01.015.

Johnson, S., Cooper, C., Cartwright, S., Donald, I., Taylor, P., \& Millet, C. (2005). The experience of work-related stress across occupations. Journal of Managerial Psychology, 20, 178-187.

Kabat-Zinn, J. (2011). Some reflections on the origins of MBSR, skillful means, and the trouble with maps. Contemporary Buddhism, 12, 281-306. https://doi.org/10.1080/14639947.2011.564844

Kokkinos, C. M. (2007). Job stressors, personality and burnout in primary school teachers. British Journal of Educational Psychology, 77, 229-243.

Kurt, T. \& Gümüş, T. (2015). Dünyada yükseköğretimin finansmanına ilişkin eğilimler ve Türkiye için öneriler. Yükseköğretim ve Bilim Dergisi, 5(1), 14-26.

La Placa, V., McNaught, A., \& Knight, A. (2013). Discourse on wellbeing in research and practice. International Journal of Wellbeing, 3(1), 116-125. https://doi.org/10.5502/ijw.v3i1.7

Lochman, J. E. (2003). Commentary: School contextual influences on the dissemination of interventions. School Psychology Review, 32, 174.

Lopes Cardozo, M.T.A \& Hoeks, C.C.M.Q. (2015). Losing ground: a critical analysis of teachers' agency for peacebuilding education in Sri Lanka. Journal of Peace Education, 12(1), 56-73. http://doi.org/10.1080/17400201.2014.940516

McLean, L. R., Cook, S., \& Crowe, T. (2008). Imagining global citizens: Teaching global citizenship education in a teacher education programme. Citizenship Teaching and Learning, 4(1), 50-64.

Mercer, S., \& Gregersen, T. (2020). Teacher wellbeing: Oxford handbooks for language teachers. Oxford University Press.

Mifsud, M. (2011). The relationship of teachers' and students' motivation in ELT in Malta: A mixed methods study. [Doctoral thesis]. http://eprints.nottingham.ac.uk/12983/1/555348.pdf

Miller, J.P. (2012). Contemplative practices in teacher education: what I have learned L. Groen, E. Coholic, E.J.R. Graham (Eds.), Spirituality in Education and Social Work: An Interdisciplinary Dialogue. Wilfrid Laurier Press.

Moolenaar, N. M. (2010). Ties with potential: Nature, antecedents, and consequences of social networks in school teams. [Doctoral thesis], University of Amsterdam. http://dare.uva.nl/record/339484.

Navarro-Castro, L. (2010). Towards a holistic approach to peace education: a Philippine perspective. Zeitschrift für internationale Bildungsforschung und Entwicklungspädagogik, 33(4), S. 13-17.

Navarro-Castro, L., \& Nario-Galace, J. (2008). Peace education: A pathway to a culture of peace. Center for Peace Education. Quezon City. 
Noddings, N. (2012). Peace education: How we come to love and hate war. Cambridge University Press.

Rath, T. \& Harter, J. (2010). Wellbeing: The five essential elements. Brilliance Audio

Roffrey, S. (2012). Pupil wellbeing - teacher wellbeing: Two sides of the same coin? Educational and Child Psychology, 29(4).

Schwind J.K., McCay E., Beanlands H., Martin, LS, Martin, J. \& Binder, M. (2017). Mindfulness practice as a teaching-learning strategy in higher education: A qualitative exploratory pilot study. Nurse Education Today, 50, 92-96. http://doi.org/10.1016/j.nedt.2016.12.017

Seligman, M. E. P., Ernstb, R. M., Gillhamc, J., Reivicha, K., \& Linkinsd, M. (2009). Positive education: positive psychology and classroom interventions. Oxford Review of Education, 35(3), 293-311. http://dx.doi.org/10.1080/03054980902934563

Shapiro, S. L., Brown, K. W. \& Astin, J. A. (2008). Toward the integration of meditation into higher education: A review of research. Center for Contemplative Mind in Society. http://www.contemplativemind.org/files/MedandHigherEd.pdf

Sidelinger, RJ, Frisby, BN, \& Heisler, J. (2016). Students' out of the classroom communication with instructors and campus services: Exploring social integration and academics. Learning and Individual Differences, 47, 167-171.

Simsek, H. (2007). Turkey. In J. Forest, \& P. Altbach (Eds.), International Handbook of Higher Education (pp. 1003-1018). Springer.

Smalley, S. L., \& Winston, D. (2010). Fully Present: The science, art, and practice of mindfulness. Da Capo Lifelong Books.

Soini, T., Pyhältö, K., \& Pietarinen, J. (2010). Pedagogical well-being: Reflecting learning and well-being in teachers' work. Teachers and Teaching: Theory and Practice, 16(6), 735-751. http://dx.doi.org/10.1080/13540602.2010.517690

Soutter, A.K., O'Steen, B., \& Gilmore, A. (2012). Wellbeing in the New Zealand Curriculum. Journal of Curriculum Studies, 44, 111 - 142.

Spilt, J. L., Koomen, H. M. Y., Thijs, J. T., \& Van der Leij, A. (2011). Supporting teachers' relationships with disruptive children: The potential of relationship-focused reflection. Human Attachment and Development, 14(3), 305-18. http://doi.org/10.1080/14616734.2012.672286

Şinik, E. (2018). Genleriniz Kaderiniz Değildir. Libros Kitap.

Trifonas, P. P., \& Wright, B. (2011). Critical issues in peace and education. Routledge: NY.

Van Veen, K., Sleegers, P., \& van de Ven, P.H. (2005). One teacher's identity, emotions, and commitment to change: A case study into the cognitive-affective processes of a secondary school teacher in the context of reforms. Teaching and Teacher Education, 21, 917-934.

Vesely, A. K., Saklofskea, D. H., \& Nordstokkeb, D. W. (2014). EI training and pre-service teacher wellbeing. Personality and Individual Differences, 65, 81-85. https://doi.org/10.1016/j.paid.2014.01.052 
Wang, H. (2018). Nonviolence as teacher education: A qualitative study in challenges and possibilities. Journal of Peace Education, 15(2), 216-237.

Westheimer, J. (Ed). (2007). Pledging allegiance: The politics of patriotism in America's schools. Teachers College Press.

Zamir, S. (2009). Universal obstacles to peace education. In A. Aharoni (Ed.), Peace, literature, and art [vol. I]. Encyclopedia of life support systems. EOLSS Publishers.

Zartman, I. W. (2007). Peacemaking in international conflict: Methods and techniques. United States Institute of Peace.

Zembylas, M., Charalambous, C., Charalambous, P. (2016). Peace Education in a conflictaffected society. Cambridge University Press.

Zembylas, M., and Bekerman, Z. (2019) Engaging with teachers' difficult knowledge, seeking moral repair: the entanglement of moral and peace education. Journal of Peace Education, 16(2), 155-174. http://doi.org/10.1080/17400201.2018.1555154

Zembylas, M., and Loukaidis, L. (2020). Affective practices, difficult histories and peace education: An analysis of teachers' affective dilemmas in ethnically divided Cyprus. Teaching and Teacher Education, 97, 103225. http://doi.org/10.1016/j.tate.2020.103225 